Journal of Education Culture and Society No. 2_2013

\title{
PSYCHOLOGICAL READINESS OF STUDENTS TO WORK IN A PROFESSIONAL FIELD
}

\author{
OLHA UHRYN \\ ougryn@gmail.com \\ Lviv State University of Internal Affairs, Ukraine

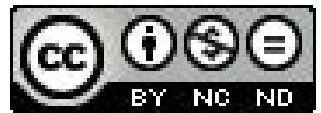

\begin{abstract}
The article is devoted to the psychological readiness of student's personality for professional life. The author considers components of readiness that promote self-development and self-realisation in the professional sphere, and presents the results of an empirical study of willingness to work in a professional field.

Key words: psychological readiness, partial readiness to self-development, professional life.
\end{abstract}

Readiness for professional activity in the chosen field is an issue of utmost importance for students. Psychological readiness is one of the most important conditions of successful self-realisation in professional life. It involves a conscious choice of a profession in accordance with the person's skills and abilities, awareness of his/her own needs, demands of the society and the person's team, set goals, manifestation of their intellectual, emotional and willed processes, the correlation between personal capabilities, level of aspiration and necessary achievements in something. A person's psychological readiness for professional development in a chosen profession determines his/her competitiveness and potential for success.

The aim of the article is to determine the notion of "psychological readiness for professional life" and to analyse the results of an empirical study of the partial readiness for professional activity in the context of family values and relationship between family members.

Readiness has been the object of specialised studies since the late XIX and early $X X$ century, when it was considered in the context of human mental processes. This period is covered in the first section of this study. On the second stage readiness is analysed as a certain phenomenon of human resistance to external and internal influences. According to O. F. Lynenko (Lynenko, 1999), the third phase of study of the concept of readiness associated with research in the theory of activity is considered in relation to emotionally-willed and intellectual potential of the individual for specific activity. Therefore, readiness is a qualitative criterion of self-regulation at different levels of the processes: physiological, psychological, and social.

The study of individual and specific characteristics of this phenomenon contributed to the creation of several concepts of psychological readiness, in particular the concepts of M. I. Dyachenko and L. A. Kandybovycha (Dyachenko, Kandybovych ,1976), as well as A. Ts. Puni (Puni, 1973). 
There are different approaches to the interpretation of a person's readiness for professional life. Thus, summarising various aspects of using the notion of "willingness to work", Yu. P. Povarenkov (Povarenkov, 2006) considers it as a complex, integral personality formation composed of moral and volitional quality of personality, socially important motives, practical skills and abilities, psychological functions and features necessary for professional life.

In contrast to the presented views, psychological readiness for professional life is analysed through the prism of the knowledge and skills that allow specialists to keep up with the requirements of modern science and technology and include a conscious choice of profession according to one's abilities and capabilities (Bochelyuk, Bilousov, Goriyanj, 2007, pp. 1-4). Thus, according to R. I. Luchechko (Luchechko, 1994), readiness to work should include the existence of individual aptitudes, specialised knowledge, expertise and skills, as well as a set of individual psychological, mental and personal features that provide for the person's high performance.

Therefore, psychological readiness on the one hand includes a stock of professional knowledge and skills, and on the other - personality traits: beliefs, skills, interests, professional memory, thinking, attention, professional orientation of thought, performance, emotional and moral potential of the individual that will provide for the successful fulfilment of professional functions (Bochelyuk, Bilousov, Goriyanj, 2007, pp. 1-4). It envisages professional orientation (readiness for professional training), direct process of mastering the knowledge and skills within the occupation (professional readiness), existence of personal traits corresponding to the nature of activity (personal readiness) and adaptation to the profession after training (professional adaptation).

The results of professiographic studies of various occupations (Klimov, 1995), proficiency in activities, professional identity (Klimov, et al., 1995) and professional orientation are very important for understanding the nature of psychological readiness of students for professional activity.

The results of the studies of readiness for activity at the stage of professional training in universities are presented in the theory of readiness (Conley, 2007), transition theory (Tinto, 2006/2007), the longitudinal model of Student departure (Tinto, 2006/2007), and the psychological model of College Student retention (Bean, \& Eaton, 2000, pp. 48-61).

Thus, the readiness of students is determined by the skills and ability to carry out the tasks in the process of activity, particularly in education (Lazzaro, Crenshaw, 2012). It is determined by the following characteristics: intellectual openness, curiosity, the ability of texts and data interpretation, accuracy of thinking, relevant skills (Conley, 2007). It requires three main elements: basic academic knowledge and skills, the ability to apply these skills in specific situations for functioning at the workplace and in everyday life, the application of special skills necessary in any field. These skills were highlighted by numerous studies and allow students to find the right career path (What is "career ready"? , 2010).

Within the structure of students' readiness for studying and working, the following elements are singled out: cognitive strategies, knowledge, conceptual 
knowledge and understanding, academic behaviour. Cognitive strategies are the central element (Conley, 2007, p. 8).

Studying psychological characteristics of students' readiness for professional life the following components can be singled out (Dyachenko, Kandybovych, 1976):

- the motivational component - it includes professional orientation, interests, and desire to engage in professional work; it is based on professional orientation (personal desire to apply knowledge in a chosen professional field) which expresses a positive attitude of the person towards his/her profession, inclination and interest in it, the desire to improve his/her professional level, etc.; professional orientation determines stability, depth and scope of professional interests and pedagogic ideals; the degree of professional interests' maturity determines the nature of future specialist's self-cultivation towards the application of his/her skills and abilities;

- the orientational component - it is based on work ethic, professional ideals, views, principles, beliefs, and readiness to act according to them; its core component is value orientations of the personality, depth of professional outlook; its main structural units include generalised professional knowledge, views, beliefs, principles and readiness to act according to them in practice; orientational aspect is an important characteristic of psychological readiness for professional life and therefore the entire educational process in higher education institutions should be built so that all forms of work promote the formation of the students' responsibility, professional ethics, ability to bring reasonable demands to their logical conclusion, correlate them with the abilities of those to whom they are addressed;

- the cognitive-operational component - it includes professional orientation of attention, ideas, perception, memory, thinking, abilities, knowledge, actions, operations and activities necessary for successful professional activity; purposeful formation of professional attention, memory, and understanding is an important factor in psychological readiness improvement; professional thinking is in a strong position among the qualities of cognitive-operational component of operational readiness; it is expressed in the ability to identify situations, events, facts, to recognise and model them, to predict possible consequences;

- the emotional-volitional component - it characterises the feeling, volitional processes that ensure successful progress and effectiveness of the teacher's performance: emotional tone, emotional sensitivity, purposefulness, self-control, persistence, initiative, determination, independence, self-criticism, self-control; within desirable qualities providing for psychological readiness for professional activities, the following are singled out: determination (managing the work with a specific purpose), self-control and endurance (maintaining self-control in any situation), persistence (long-term maintenance of efforts at achieving the goal), initiative (willingness and ability to be creative in solving problems, amateur performance of professional functions), decisiveness (timely and reasonable decision-making and prompting their implementation), independence (relative resistance to external influences), self-criticism (ability to notice mistakes, wrong actions, and desire to correct them). 
An important role in the choice of future profession is played by family traditions and the desire of parents. This is supported by the theories that describe the future of professional development of a specialist from the angle of the family. Games People Play Theory of E. Berne (Berne, 2010) explains the choice of profession and professional behaviour by a scenario formed in the early childhood. According to this theory, a relatively small number of individuals achieve full autonomy in life. Thus, important aspects of life (marriage, children's upbringing, the choice of profession and career, divorce and manner of death) are guided by scenarios, namely by the program of gradual development, life plan formed in the early childhood (before the age of 6) under the influence of parents and certain behaviour. For good career scenarios to prevail, certain conditions must be kept: parents must be willing to share, and children must be ready to accept the appropriate scenario; the child must have the appropriate scenario abilities developed that do not contradict the content of the scenario of life events; parents must have their ownwinnersscenarios. On the basis of certain feelings to the grandparents and appropriate attitude to them this or that scenario is developed.

According to the theory of professional development of A. Roe (Roe, Siegelman, 1969) professional choice is seen as a direct or indirect needs satisfaction. The content of needs is primarily conditioned by the early atmosphere of the parental home and parents' styles of upbringing which, through satisfaction or frustration of primary needs, form the individual structure, including professional orientation and special abilities. The author relates professional development of the individual to the nature of child-parent relationship in the family. She singles out types of relationships based on the following parameters of interaction between parents and children: emotional acceptance/rejection, presence/absence of control, stimulation/non-stimulation of the child's activity that determine the type of direction of his/her interests, particularly professional: individual/objective, protected/unprotected, towards the others/themselves. For example, authoritarian parents may not consider the opinion, the interests of the child, and rely on their own experience. They themselves decide what the child needs, which ability he/she must have for a better life. Sometimes parents choose for the child the specialty that they would like to have, but for some reason have not obtained. This behaviour can lead to the situation when the person having obtained the proposed specialty eventually realises that it is not his/ her choice and feels dissatisfaction with work, does not want to improve himself/ herself and implement his/her potential in the given profession.

Within psychoanalytic family therapy F. Dolto, N. Abraham, I. Buzormeni-Nad (Farmer, 2010, pp. 208-211) consider career choices from the angle of passing from generation to generation. According to L. Sondi (Craig G., 2000) personality in a person's life seeks to realise the demands of his/her ancestors. This applies particularly to the important aspects of life, such as the choice of career, place of work, spouse.

The source of personal and professional dissatisfaction can be identified in particular by analysing the underlying genetic relationships between generations (Yaffe - Yanay O., 2011). For the person who strives for self-realisation, development, creativity, family serves as an educational and testing ground. 
Modern studies indicate that on average every fourth-fifth student noted the influence of parents on the choice of profession. The number of students (average $15 \%$ ) who, deciding to study at university, motivated it by continuing the carefree period of life, is quite significant. Therefore, for a significantly large number of students studying at universities is a way to postpone active involvement in adulthood, which is accompanied by psychological unpreparedness for professional development and learning within the very professional sphere.

That is why an empirical study was conducted to examine the components of students' partial readiness for professional life and self-development in the context of family values and relationships within the family in order to determine their role in the professional development and identity formation.

The study involved 356 people aged 19-22.

To detect partial preparedness for professional self-development the method of "Diagnostics of the level of partial preparedness for professional and pedagogic self-development" was used. The level of readiness components was determined, basing on this method. Among the included components of partial readiness were: motivation, cognitive, moral-willed, gnostic and organisational skills, self-management ability and communication. The "Methodology of assessing the level of self-actualisation" ("SAMOAL") was also applied.

In order to establish the role played by family values, relationships in a family and the behaviour of parents in the formation of psychological readiness of student's personality to professional activity "The scale of family environment" was used (Eydemiller E.G., Dobryakov I.V., Nikol'skaya I.M., 2007, pp. 63-68; Questionnaire "Value orientation in the sphere of family relations"). And to test the significance of the empirical results obtained, the static methods of data processing were applied: Pirson's correlation analysis and single-factor analysis of variance (Scheffe test) in the program STATISTICA 8.0.

Correlation analysis indicates the existence of direct links between the components of readiness for professional self-development and the desire for self-actualisation (Table 1).

The results obtained indicate that with formation and development of the components of readiness for activity the desire for self-actualisation in the professional sphere will also be developed.

In addition, the analysis confirmed the assumption that there exists an interrelation between the readiness to work in a professional field and the parameters of the family, including relationships in the family and family values. Let us consider only the most significant ones (Table 2).

So, if in a family there is freedom, broadness of external relations, flexible upbringing, depth of family ties, commitment to the interests both of the family and the society, the intensification of components of readiness for professional activity takes place.

The families in which there is unity, independence, expressiveness, achievements orientation, intellectual and cultural development and observance of moral-ethical norms of society contribute to the development of these components of readiness.

Therefore, the results indicate the significant influence of the family values, relationships in the family and the desire for self-realisation in the chosen profession development on the components of readiness. 


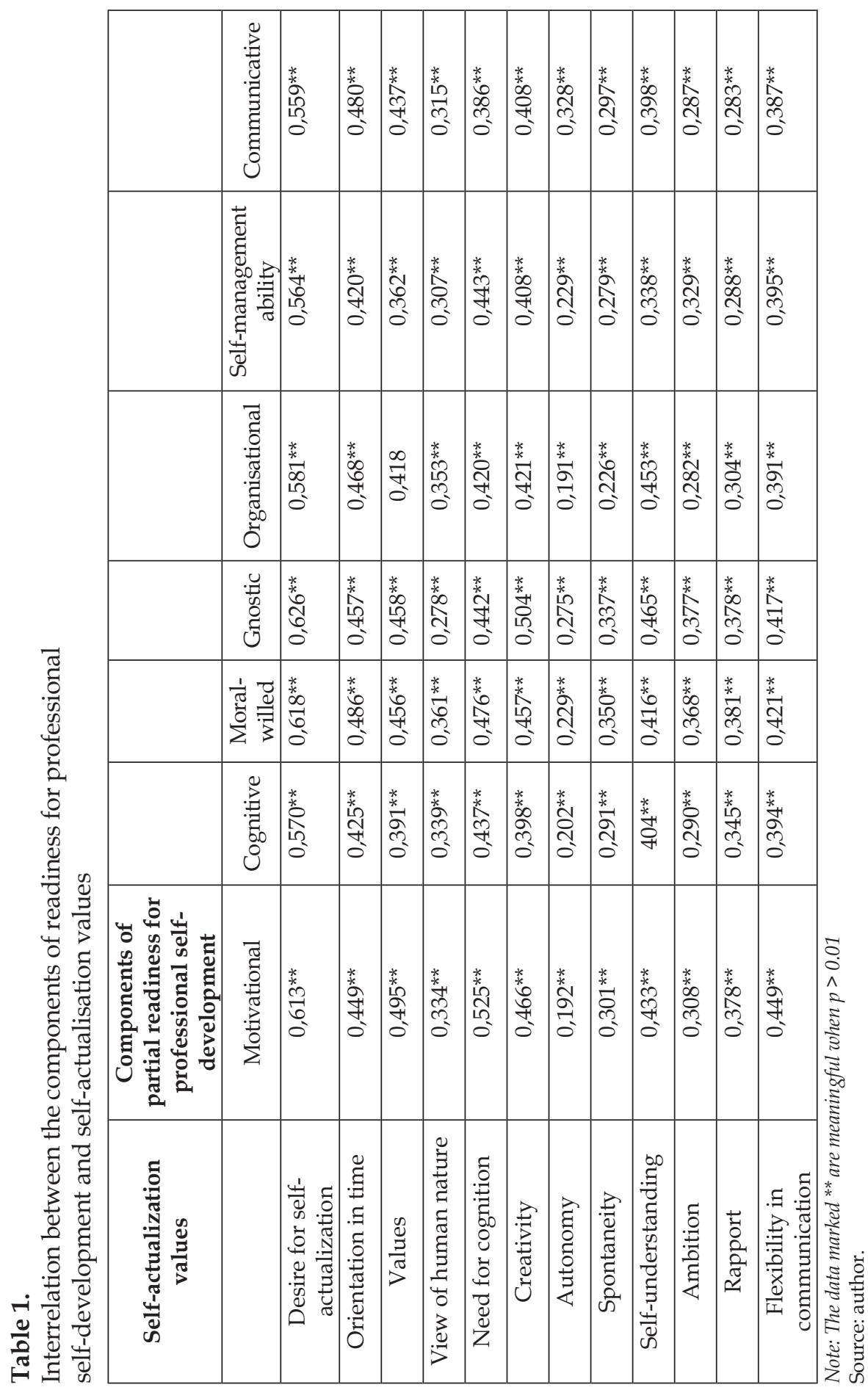




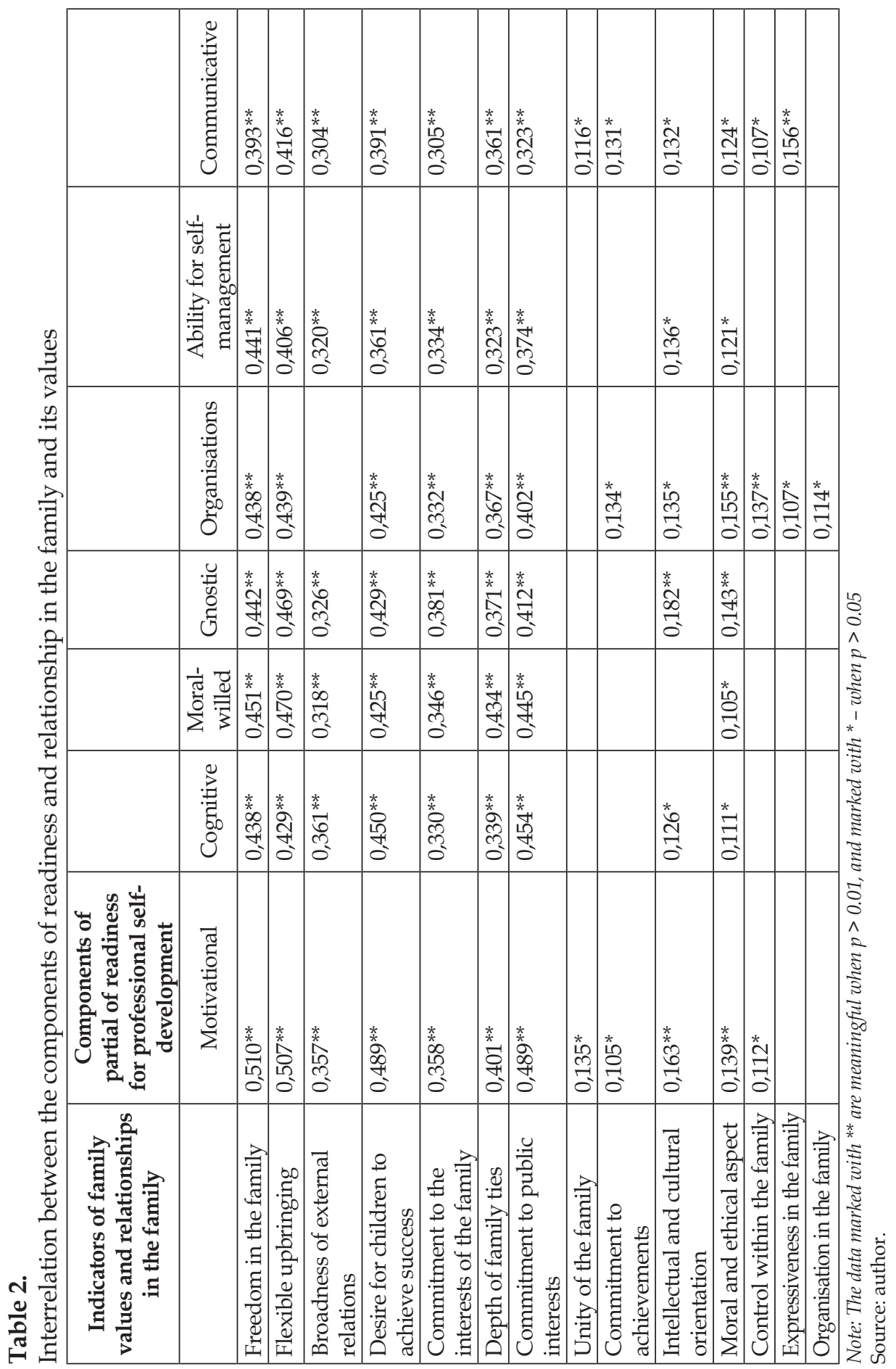


Factors that contribute to the development and improvement of the level of this or that readiness component are following:

- motivational component - the desire for self-actualisation; orientation in time; the value of self-actualisation; the view of human nature; the need of cognition; creativity; autonomy; spontaneity; self-understanding; ambition; rapport; flexible communication; freedom in the family; flexible upbringing; broadness of external family connections; the desire for children to achieve success; commitment to the interests of the family; the depth of family ties; commitment to the interests of society; the family unity; achievement orientation; intellectual and cultural family orientation; moral and ethical aspect; control within the family;

- cognitive component - the desire for self-actualisation; orientation in time; the value of self-actualization; view of human nature; the need for knowledge; creativity; autonomy; spontaneity; self-understanding; self-likeness; contact ability; flexible communication; freedom in the family; flexible education; broadness of external family connections; the desire for children to achieve success; commitment to the interests of the family; the depth of family ties; commitment to the interests of society; intellectual and cultural family orientation; moral and ethical aspect;

- moral-willed component - the desire for self-actualisation; orientation in time; the value of self-actualisation; view of human nature; the need for cognition; creativity; autonomy; spontaneity; self-understanding; ambition; rapport; flexible communication; freedom in the family; flexible upbringing; broadness of external family ties; the desire of children to achieve success; commitment to the interests of the family; depth of family ties; commitment to the interests of society; moral and ethical aspect;

- gnostic component - the desire for self-actualization; orientation in time; the value of self-actualization; view of human nature; the need for cognition; creativity; autonomy; spontaneity; self-understanding; ambition; rapport; flexible communication; freedom in the family; flexible upbringing; broadness of external family ties; the desire for children to achieve success; commitment to the interests of the family; the depth of family ties; commitment to the interests of society; intellectual and cultural family orientation; moral and ethical aspect;

- organizational component - the desire for self-actualisation; orientation in time; the value of self-actualisation; the view of human nature; the need for cognition; creativity; autonomy; spontaneity; self-understanding; ambition; rapport; flexible communication; freedom in the family; flexible upbringing; the desire for children to achieve success; commitment to the interests of the family; commitment to the interests of society; achievement orientation; intellectual and cultural family orientation; moral and ethical aspect; control within the family; expressiveness in the family; organisation in the family;

- ability of self-management - the desire for self-actualisation; orientation in time; the value of self-actualisation; view of human nature; the need for cognition; creativity; autonomy; spontaneity; self-understanding; am- 
bition; rapport; flexible communication; freedom in the family; flexible upbringing; the broadness of external family ties; the desire for children to achieve success; commitment to the interests of the family; the depth of family ties; commitment to the interests of society; intellectual and cultural family orientation; moral and ethical aspect;

- communicative component - the desire for self-actualisation; orientation in time; the value of self-actualisation; view of human nature; the need for cognition; creativity; autonomy; spontaneity; self-understanding; ambition; rapport; flexible communication; freedom in the family; flexible upbringing; broadness of external family ties; the desire for children to achieve success; commitment to the interests of the family; commitment to the interests of society; unity in the family; achievement orientation; intellectual and cultural family orientation; moral and ethical aspect; expressiveness in the family; control within the family.

Comparative analysis of the level of readiness for professional activity was also conducted. The statistical differences between the groups with high, medium and low readiness for activity in the professional field were checked with the help of single-factor dispersion analysis by H. Sheffe, where $\mathrm{p}<0.05$ (Fig. 1).

Thus, students with high level of readiness for professional activity, as compared to the individuals with average and low levels, show higher values according to the following scales: the desire for self-actualisation and its value, orientation in time, view of human nature, the need for cognition, creativity, self-understanding and rapport. This is reflected in the fact that they seek to realise their potential without putting their lives away for better and without focusing on the past, but with enjoying the actual moment of life. Those students believe in the power of human potential, which is a stable basis for sincere and harmonious interpersonal relationships, fellow feeling and confidence in people, honesty, and benevolence. These are sociable people who can establish strong and friendly relationships with others, are amenable to mutually beneficial and pleasant contacts with other people.

Also, they are characterised by a creative attitude to life, they unselfishly strive for something new, and they show interest in the actual objects and values.

Of course, there are also higher values of readiness components, including motivational, cognitive, moral-willed, gnostic, organisational, communicational and the ability to self-management.

As for the impact of families on the persons with high levels of readiness, the importance of family values (freedom in the family, flexible upbringing, personality expression, the broadness of external family ties, marriage in adulthood) and an emphasis on the intellectual and cultural development of each family member are to be outlined.

\section{CONCLUSIONS}

Students' readiness for professional activity is determined by the requirements of the very activity as to the mental processes, states and properties of the person, motivation in the given profession, personality orientation, as well as life and pro- 


|

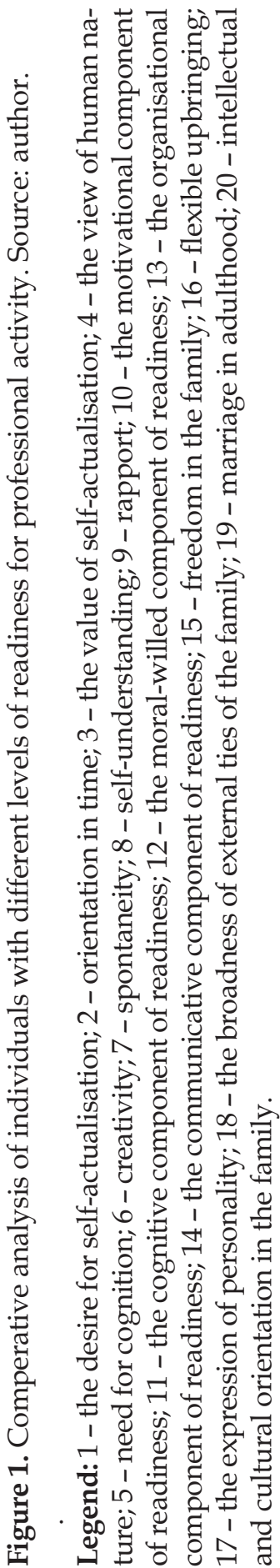


fessional experience of the person. Well-developed psychological readiness for a profession is an important component of student's self-improvement increasing self-realisation in the professional sphere.

Basing on presented empirical research, an interrelation between the components of readiness for professional activity, family values and the relations between family members was established. Family influences the improvement of a given component of readiness for professional activity, what in turn facilitates self-realisation in the chosen field. Besides, the study revealed the features that characterise individuals with a high level of readiness for professional activity.

\section{REFERENCES}

Бочелюк В.Й., Білоусов Г.О., Горіянь Г.О. (2007). Професіоналізм особистості: теоретико методологічнии аспект [Professionalism personality: theoretical - methodological aspect]. Запоріжжя: GU "Humanities".- 247p.

Conley, D. (2007), Towards a more comprehensive conception of College Readiness. A report prepared for the Bill and Melinda Gates Foundation. Eugene, OR: Educational Policy Improvement Center, Retried form http://www.smallschoolsproject.org/PDFS/meetings/conley_college_ready.pdf.

Дьяченко М. И., Кандибович Л. А. (1976). Психологическая проблема готовности к деятельности [Рsychological problem of readiness to activity]. Минск: Publishing house of BGU. - 176p.

Эйдемиллер Э.Г., Добряков И.В., Никольская И.М. (2007). Семейный диагноз и семейная психотерапія [Domestic diagnosis and domestic psychotherapy]. Санкт - Петербург: Speech. - 357p.

Климов, Е. А. (1995). Образ мира в разнотипных профессиях [World Appearance in different professions]. Москва: М. - 180p.

Крайг, Г. (2000). Психология развития [Рsychology of development]. Санкт - Петербург: Peter. - 992p.

Линенко, А. Ф. (1999). Теория и практика формирования готовности студентов педагогических вузов к профессиональной деятельности:дис..д-ра пед.наук [Theory and practice of formation of readiness future teachers to the profession: dis .. Dr. ped.nauk]. Киров.

Лучечко, Р. І. (1994). Формування готовності старшокласників сільської иколи до трудової діяльності в умовах ринкових відносин: Дис. . канд. пед. наук: 13.00.01. [Forming of readiness of senior pupils of rural school is to labour activity in the conditions of market relations: Dis. . kand. ped. sciences: 13.00.01.]. Киров. - 147p.

Поваренков, Ю. П. (2006). Введение в психологию труда [Introduction to the psychology of work]. Москва: М.

Пуни, А. Ц. (1973). Некоторые психологические вопросы готовности к соревнованиям в спорте [Some psychological issues readiness to compete in the sport]. Москва: Physical Education and Sports. - 113p.

Яффе - Янаи, О. (2011). Генетический код личности. Как найти и реализовать свое призвание [The genetic code of the individual. How to find and realize their vocation]. Киев: Publ.Alex Capusta. - 240p.

Bean, J., Eaton, S. (2000). A psychological model of college student retention, In: J. Braxton (Ed.), Reworking the departure puzzle: New theory and research on college student retention (pp.48-61). Nashville, TN: Vanderbilt Universities Press.

Berne, E. (2010). Games People Play: The Psychology of Human Relationships. Harmondsworth: Penguin.

Conley, D. T. (2007). Redefining college readiness, vol.3, Eugene. OR: Educational Policy Improvement Center.

Conley, D. (2007), Towards a more comprehensive conception of College Readiness. A report prepared for the Bill and Melinda Gates Foundation. Eugene, OR: Educational Policy Improvement Center, Retried form http:/ / www.smallschoolsproject.org/PDFS/meetings/conley_college_ready.pdf.

Farmer R. (2010), Humanism, Self-Actualization, and Social Studies, “.The Social Studies" no..5, pp.208 - 211.

Lazzaro C., Crenshaw D. (2012), College-readiness in Science, Retired form http:/ / www.ride.ri.gov/instruction/DOCS/NGSS/College_Board-Science_College_Readiness.pdf.

Roe, A., Siegelman, M. (1969). The origin of interests. Washington: APGA. - 98p.

Tinto, V. (2006/2007). Research and practice of student retention: what next?, "Journal of College Student Retention.8(1), pp.1-19

What is "career ready"?(2010)., Retried from http://www.acteonline.org/uploadedFiles/Publications_ and_Online_Media/files/Career_Readiness_Paper_COLOR.pdf . 